Bence Tóth ${ }^{1}-$ Zsolt Lévai $^{2}$

\title{
The strategic role of the former railway bridge at Dunaföldvár
}

\author{
DOI 10.17047/Hadtud.2021.31.E.67
}

With the suspension of the investment into the V0 railway line, the issue of the railway lines bypassing Budapest came to the front again. As an alternative of building a new railway line, the development of existing ones or the rebuilding of lines that have been in operation in the past should be examined. In this paper, we deal with a previously operated, now discontinued Danube crossing facility, the Solt-Dunaföldvár railway bridge. Although this crossing was of minor importance during its operation, it is worth examining the role it can play should it be rebuilt with parameters required for a TEN-T railway line. According to our graph-theory based calculations, such a bridge cannot only be part of the only reasonable detour if the Southern Railway Bridge in Budapest is disrupted but can also be a facility disencumbering it under normal operational conditions.

KEYWORDS: railway, Danube bridge, graph theory, critical infrastructure, redundancy

\section{Az egykori dunaföldvári vasúti híd stratégiai szerepe}

A V0 vasútvonal kiépitésének határozatlan idöre történö elhalasztásával a Budapestet elkerülö vasútvonalak helyzete ismét elötérbe került. Egy teljesen újonnan építendö vasútvonal alternativájaként célszerü megvizsgálni létező vasútvonalak fejlesztését, illetve egykor létezettek újraépítését. Cikkünkben a 2001-ben megszüntetett Solt és Dunaföldvár közötti vasúti átkelési lehetőség szerepével foglalkozunk. Bár létezése alatt ennek a hídnak nem volt jelentös forgalma, érdemes megvizsgálni, milyen szerepet játszana a hálózatban ha a TEN-T vonalak müszaki paramétereinek megfelelöen építenék újra. Gráfelméleti alapú számitásaink azt mutatják, hogy egy ilyen módon újjáépített híd nem csak az Összekötö vasúti híd egyetlen reális kerülöútjaként lenne számításba vehetö, hanem azt normál üzemi körülmények között is tehermentesithetné.

KULCSSZAVAK: vasút, Duna-híd, gráfelmélet, kritikus infrastruktúra, redundancia

\section{Introduction}

Transportation networks, being critical infrastructures of our society in both peace and war, have to be maintained by taking into account all possible and plausible criteria. In the case of railway networks, abandoning a line due to low passenger and/or freight demand should not affect significantly the vulnerability of the network as a whole. ${ }^{3}$ This means, for example, that

\footnotetext{
1 Department of Natural Sciences, Faculty of Military Sciences and Officer Training, University of Public Service; e-mail: toth.bence@uni-nke.hu; https://orcid.org/0000-0003-3958-187X

2 Doctoral School of Military Engineering, University of Public Service; research fellow, KTI Institute for Transort Sciences; e-mail: levai.zsolt@uni-nke.hu; https://orcid.org/0000-0003-2410-1730

${ }^{3}$ Crucitti et al. 2003; Crucitti et al. 2004; Mattsson and Jenelius 2015.
} 
a single-track line with lower line speed and without electrification still has to be maintained if it is the only alternate route between two important stations, especially when it connects the locations of troops of the Hungarian Defence Forces to the national railway network.

The most critical points of the railway network of Hungary are the bridges of the river Danube, as currently there are only three of them within the country, which number and their density is insufficient for reasonable operation. ${ }^{4}$ Two are in Budapest (the Újpest Railway Bridge and the Southern Railway Bridge) and one, the Baja Railway Bridge, is 144 kilometres down the Danube River near the southern border of the country. The Újpest and the Baja bridges are not part of the core railway network, both of them are single tracked, their connecting railways are not electrified in their whole length, therefore the role of these bridges in the network is marginal. As a consequence, the east-west transport direction passes through the Southern Railway Bridge at the capital of the country. Though being the common element of all TEN-T corridors passing through the country, this bridge has no alternative route for any case of disturbance in the traffic. ${ }^{5}$ Through the railway network of Hungary, an effective connection is provided between Western Europe and Turkey via the Balkans, between Southern Europe and Russia via Ukraine, and is also an important link in the transportation between the North Sea, the Baltic Sea, the Mediterranean and the Black Sea ${ }^{6}$ with all these routes passing through one single network element.

In this paper, we will concentrate on a former railway bridge on the Danube and its role in the railway netwok of Hungary as a critical infrastructure, was it preserved and developed along with its connecting railway lines. This bridge was located in the middle of the country between Dunaföldvár and Solt. The analysis of the possible rebuilding of this bridge with strategically better paths is the topic of future research and thus will be presented in an upcoming paper.

\subsection{The V0 railway line}

The so-called V0 railway line is a long-planned alternative to the only double-track electrified Southern Railway Bridge in Budapest, as a bypass running from the East to West without entering the capital. The idea arose as early as after WWI but only in 2012 was a path designated to it based on the study of the Association of Hungarian Logistics Service Centers (Magyar Logisztikai Szolgáltató Központok Szövetsége, MLSZKSZ, see (URL1)). However, it was not included into the Integrated Transportation Operative Programme (IKOP) (Homolya, s.a.) nor is it a priority for transportation development plans (Mosóczi, 2019). This is because the Budapest Intermodal Logistics Center (BILK), the main container transfer station of the country, is in Budapest and therefore freight trains have to enter the city to exchange their loads.

\footnotetext{
${ }^{4}$ Lakatos et al. 2016.

${ }^{5}$ Szászi 2007.; Horváth 2005.

${ }^{6}$ Horváth 2009.
} 


\subsection{The condition of the Southern Railway Bridge}

The condition of Southern Railway Bridge gets worse with time, as the two distinct structures for the two tracks were built in 1948 and 1953, respectively. Therefore, in 2018 two Government decrees were issued that envisage the building of a third track on the existing pillars (URL2), (URL3), after which the reconstruction of the existing two tracks can be carried out. However, this third track will not make the network cease to depend one this single network element but makes the situation worse by increasing the traffic passing through it instead. ${ }^{7}$ The only solution to the problem is a bridge outside the capital. ${ }^{8}$

\subsection{The Dunaföldvár bridge as an alternative to VO}

Because of the suspended construction of the V0 railway line, we are now focusing on the crossing at Dunaföldvár, which previously existed but since has been abandoned. The $13 \mathrm{~km}$ long Solt-Dunaföldvár railway line with number 151a was put in operation in 1940. The line crossed the Danube on the bridge at Dunaföldvár, which was originally built for solely road traffic. The line was planned to be the part of the ,inner railway ring”, which was an early plan for the already mentioned V0 line. This would have continued from Solt through Fülöpszállás and Kecskemét but this part was never built (but the mileage of the line was, however, counted from Fülöpszállás). After WWII, the bridge was repaired and traffic was put back in 1951. Passenger traffic was ceased in 1978 and during the 2000/2002 reconstruction of the bridge the tracks were removed. Today, there is no passenger traffic in either Dunaföldvár or Solt railway stations.

But what would be the situation in the railway network today if the bridge and the connecting lines had been developed? To be able to answer this question we have analyzed three scenarios all assuming the bridge and the 151a line to be extant and the connecting railway lines be suitable for traffic.

First, the $13 \mathrm{~km}$ long Solt-Dunaföldvár line was assumed to be available for 60 $\mathrm{km} / \mathrm{h}$ line speed and the connecting lines with their actual line speed (FIG. 1, top left). Second, together with the Solt-Dunaföldvár line, the connecting Solt-KunszentmiklósTass (line 151), Dunaföldvár-Pusztaszabolcs (line 42) and Dunaújváros-Rétszilas (line 43) were taken into account with $120 \mathrm{~km} / \mathrm{h}$ line speed (FIG. 1, bottom left). Third, additionally to the second scenario, the whole Budapest-Kelebia (line 150) was put in the model with $120 \mathrm{~km} / \mathrm{h}$ line speed (FIG. 1, right). This latter scenario takes into account the result of the ongoing rebuilding of the Hungarian part of the Budapest-Belgrade railway line which is planned to finish in 2025 .

\footnotetext{
${ }^{7}$ Szászi 2013.

${ }^{8}$ Szászi 2014.
} 


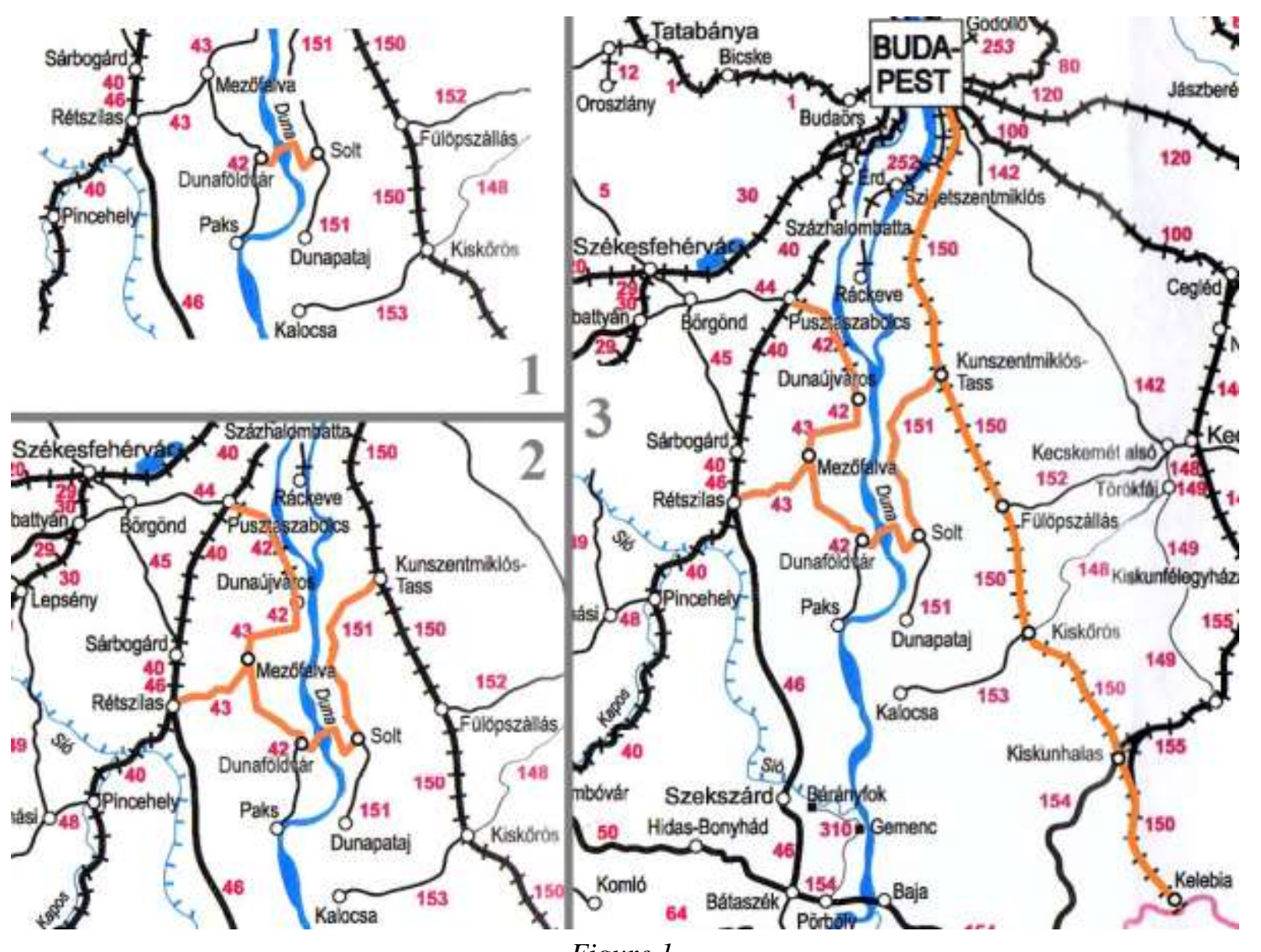

Figure 1.

The three scenarios to include the Dunaföldvár bridge into the railway network of Hungary. Top left: scenario \#1, railway line 151 a marked with orange, line speed $60 \mathrm{~km} / \mathrm{h}$. Bottom left: scenario \#2, railway line 151a, 42, 43 and 151 marked with orange, line speed $120 \mathrm{~km} / \mathrm{h}$. Right: scenario \#3, railway line 151a, 42, 43, 150 and 151 marked with orange, line speed $120 \mathrm{~km} / \mathrm{h}$.

(Made by authors based on URL4)

The aim of these scenarios was to analyze how the importance of the bridge would evolve with continuous development of the connecting railway lines in the complex railway network of the country. After presenting the methods used for the analysis, we discuss the results of the calculations.

\section{The graph model of the railway network of Hungary}

As the model was described in detail in a previous paper ${ }^{9}$ only the elements necessary for the understanding of the model will be presented here. We used a weighted graph to model the railway network of Hungary. ${ }^{10}$ The nodes of the graph were the termini and the stations where at least two railway lines meet/branch, while intermediate stations (the so-called joint nodes), ${ }^{11}$ of lines and stops without the possibility of reversing were not included in the model. The only exceptions were the stations at which there are no sidings of the Hungarian Defence Forces

\footnotetext{
${ }^{9}$ Tóth and Horváth 2019.

${ }^{10}$ Derrible and Kennedy 2011.

${ }^{11}$ Jenelius et al. 2006.
} 
but the nearest towns are the dislocations of a unit. The edges of the graph are the line sections between the stations.

The calculations were performed with two different weights assigned to each edge, the length and the travel time of the corresponding line section. The travel time of a line section was calculated as the ratio of the length of the line section and its corresponding line speed. When the line speed is different for different axle loads or for trains with locomotive and for EMUs $^{12}$, the speed for the highest axle load was taken into account and a train with locomotive was assumed, i.e., the smallest line speed value was used. The length and speed data are available publicly online on the page of the Hungarian Rail Capacity Allocation Office (Hungarian: Vasúti Pályakapacitás-elosztó Kft.) (URL5). The data for the sidings of the Hungarian Defence Forces are from a Government Decree (URL6).

For reversing, no extra trip length was assigned in the distance calculations, but 15 minutes extra travel time was added in the time calculations.

\section{Methods and measures}

Analysing the network it is important to decide whether the minimal travel time or shortest path will be the optimal for detoured trains (or for the owners of the paths). It can depend on the circumstances of the connecting lines (e.g. electrifying). When the trivial detour is also disrupted, this question has more emphasis. ${ }^{13}$

\subsection{Shortest path}

For the calculations and the visualization, the $R$ programming Language and Environment ( $\mathrm{R}$ Core Team, 2012) was used with the igraph package developed by Gabor Csardi and Tamas Nepusz. ${ }^{14}$ The shortest path between two stations (in kilometres or in minutes) can be calculated using the distances() function of the igraph package. For weighted directed graphs with no negative weights (as in our case), it uses Dijkstra's algorithm ${ }^{15}$ as a default. With the shortest_paths() function of the igraph package one can determine which edges fall on this shortest path.

Let us denote the length of the shortest path between stations $a$ and $b$ in the undisrupted network by $\ell_{a b}^{0}$ and the shortest possible travel time between stations $a$ and $b$ in the undisrupted network by $t_{a b}^{0}$. Calculating the route of the shortest paths between all $\langle a, b\rangle$ pairs of stations both for distance and time weights, an artificial flow on the network can be obtained (Fig. 2).

\footnotetext{
${ }^{12}$ Electric Multiply Unit.

${ }^{13}$ Lévai 2020.

${ }^{14}$ Csardi and Nepusz 2006.

${ }^{15}$ Dijkstra 1959.
} 


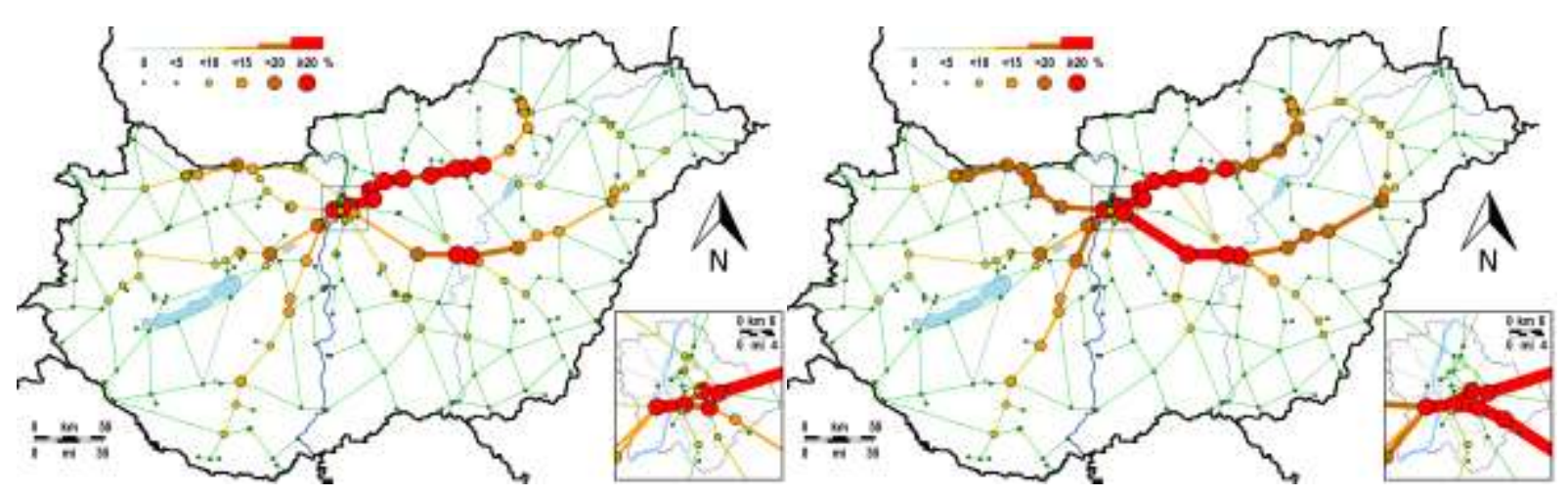

Figure 2.

The traffic flow values as a ratio to the total number of paths in the network used in the analysis for with shortest trip lengths (left) and shortest travel times (right).

(Tóth 2017.)

\subsection{Disruptions}

The term "disruption" will be used in the meaning that the given line section is not available for traffic at all, i.e. no shortest path can pass through it. This was realized by deleting the two corresponding edges of the appropriately weighted graph.

Let us denote the length of the shortest path between stations $a$ and $b$ in the network without line section $u$ by $\ell_{a b}^{u}$ and the shortest possible travel time between stations $a$ and $b$ in the network without line section $u$ by $t_{a b}^{u}$.

\subsubsection{The Network Robustness Index}

A simple but effective measure to describe the overall resilience of a network against disruptions is the Network Robustness Index (NRI) defined by (Scott et al., 2006). The NRI is calculated for all edges of the graph and based on this measure the individual line sections can be ordered by criticality.

First, the sum of the trip lengths or travel times of the shortest paths between all $\langle a, b\rangle$ pairs of stations in the undisrupted graph has to be determined, which will be denoted by $c_{\ell}$ and $c_{t}$, respectively. Then, the edges representing line section $u$ are deleted from the graph. Again, the sum of the trip lengths or travel times of the shortest paths between all $\langle a, b\rangle$ pairs of stations is calculated, denoted by $c_{\ell}^{u}$ and $c_{t}^{u}$, respectively. The NRI (denoted by $q^{u}$ ) is calculated as the difference of these two values:

$$
\begin{aligned}
& q_{\ell}^{u}=c_{\ell}^{u}-c_{\ell}=\sum_{\langle a, b\rangle} \ell_{a b}^{u}-\sum_{\langle a, b\rangle} \ell_{a b}^{0} \\
& q_{t}^{u}=c_{t}^{u}-c_{t}=\sum_{\langle a, b\rangle} t_{a b}^{u}-\sum_{\langle a, b\rangle} t_{a b}^{0}
\end{aligned}
$$

If line sections $u$ and $v$ are simultaneously deleted, the NRI is calculated as

$$
\begin{aligned}
& q_{\ell}^{u v}=c_{\ell}^{u v}-c_{\ell} \\
& q_{t}^{w v}=c_{t}^{w v}-c_{t}
\end{aligned}
$$


where $c_{\ell}^{u v}$ and $c_{t}^{u v}$ are the total network trip length or the total network travel time without line sections $u$ and $v$.

\subsubsection{The redundancy index}

The Network Robustness Index measures the increase in the total network trip length or the total network travel time in the case of the disruption of line sections. But on the disruption of line section $v$ the exact route of the shortest path between stations $a$ and $b$ changes compared to the shortest path in the undisrupted network.

Let us assume that the shortest path between stations $a$ and $b$ in the undisrupted network did not pass through line section $u$ but in the disrupted network it does. How much would be the additional increment in the shortest path if $u$ were disrupted, too? This extra increment in the trip length or travel time is called the redundancy provided by line section $u$ to line section $v^{16}$.

Paths that pass through line section $u$ neither in the undisrupted nor in the network without line section $v$ nor the ones that pass through it in both are not relevant, since they are not sensitive for the disruption of line section $u$. Therefore, only those shortest paths are taken into account for which $\ell_{a b}^{u}-\ell_{a b}^{0}=0$ or $t_{a b}^{u}-t_{a b}^{0}=0$. The $r^{u v}$ redundancy index is defined by the sum of the increase in the shortest paths in the network without both line sections $u$ and $v$ compared to the sum of the increase in the shortest paths in the network without line section $v$ :

$$
\begin{aligned}
& r_{\ell}^{u v}=q_{\ell}^{u v}-q_{\ell}^{v} \\
& r_{t}^{u v}=q_{t}^{u v}-q_{t}^{v}
\end{aligned}
$$

By calculating $r^{u v}$ for all $v$ line sections that are not identical with $u$ and summing them up one gets the total redundancy that line section $u$ provides to line section $v$ :

$$
\begin{aligned}
& r_{\ell}^{u}=\sum_{v} r_{\ell}^{u v}=\sum_{v}\left(q_{\ell}^{u v}-q_{\ell}^{v}\right)=\sum_{v}\left(c_{\ell}^{u v}-c_{\ell}^{v}\right) \\
& r_{t}^{u}=\sum_{v} r_{t}^{u v}=\sum_{v}\left(q_{t}^{u v}-q_{t}^{v}\right)=\sum_{v}\left(c_{t}^{u v}-c_{t}^{v}\right)
\end{aligned}
$$

However, if at least one station gets unreachable from the others due to the disruption of such line section(s), the value of both $q^{u}$ and $r^{u}$ becomes infinite. Therefore, it is practical to use the reciprocals of the travel time and trip length values of the shortest paths. By changing the order in which the difference is calculated in Eqs. (1)-(4), the redundancy index remains positive. Furthermore, it is more informative to normalize the obtained redundancy values with values of the total reciprocal trip length or the total reciprocal travel time of the undisrupted network (which measures are denoted by $c_{\ell}^{\prime}$ and $c_{t}^{\prime}$, respectively):

\footnotetext{
${ }^{16}$ Jenelius 2010.
} 


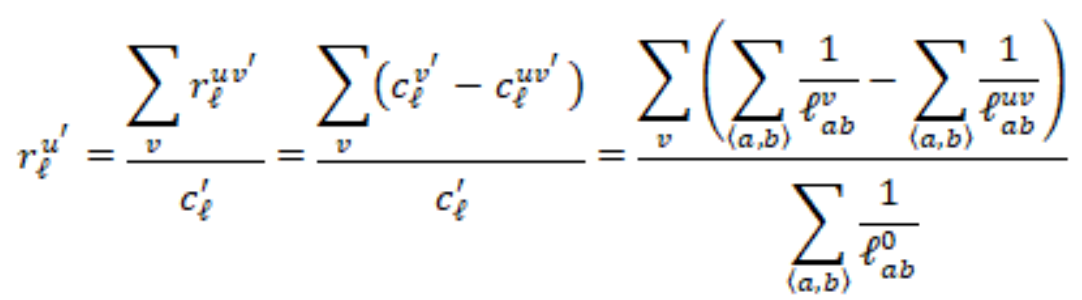

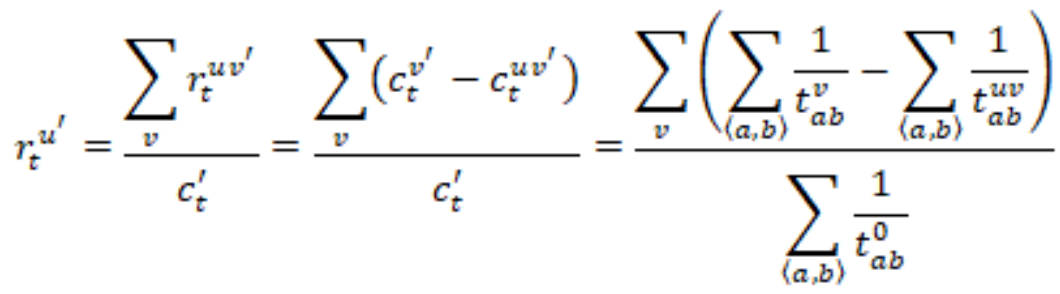

\section{Results and discussion}

In the following, four maps will be presented in each figure. As the length of the line sections were identical in all three scenarios, these results are presented in the top left part. The results of the three scenarios when applying the time weights were, naturally, different. The maps of scenario \#1 are presented in the top right part, of scenario \#2 in the bottom left and of scenario $\# 3$ in the bottom right panel.

\subsection{Traffic flow through the Dunaföldvár bridge}

In Fig. 3, the paths that cross the Danube using the Dunaföldvár bridge are visualized. It is evident at first glance that the cases of distance and time differ in an essential way. As the transverse branch lines between the radially structured main lines are present in the railway network of Hungary, these lines are used by the paths shortest in distance to reach the bridge. When arriving from the direction of Miskolc on line 80, at Budapest line 150 (BudapestKelebia) is chosen by the algorithm. Arriving from Debrecen/Nyíregyháza on line 100, line 152 (Fülöpszállás-Kecskemét) is an important part of the calculated route due to its ideal position. Also, the paths between the south-eastern and south-western parts of the country use this bridge intensively through the dense branch line network of the southeast. 

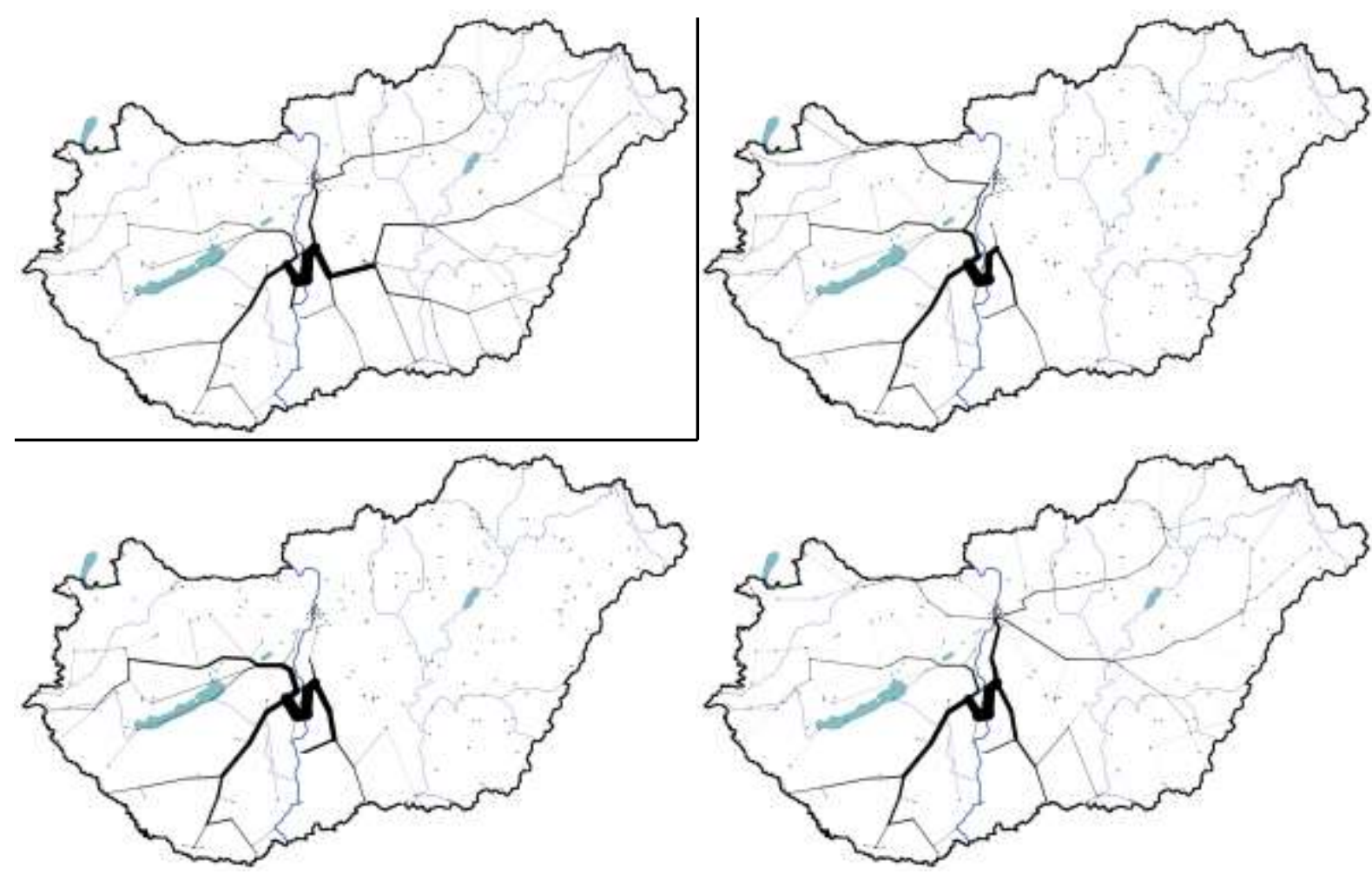

Figure 3.

The paths that cross the Danube through the Dunaföldvár bridge in each scenario. Minimal trip lengths: top left; minimal travel times scenario \#1 top right, scenario \#2 bottom left, scenario \#3 bottom right. The thickness of each line section is proportional to the number of paths passing through that line section.

(Made by authors)

However, when travel times are taken into account, the picture drastically changes. The dense but slow branch line network of the south-eastern part of the country and the previously important line 152 are no longer used as the line speed of the latter is only $20 \mathrm{~km} / \mathrm{h}$. In scenario \#1, the paths that cross the Danube at Dunaföldvár are mostly directed to Kelebia, the southern end and border crossing station of line 150. This is because only for these paths it is the fastest route, as they do not have to approach Budapest on the slow line 150 or via a longer but somewhat faster alternate route via Kecskemét and Cegléd (lines 155, 140 and 100).

The only important difference between scenarios \#1, \#2 and \#3 is the usage of line 1 (Budapest-Hegyeshalom). As line 151 on the eastern (the so-called Cisdanubia) region of the country becomes faster, there is no need for the paths between stations on this line and stations in the north-eastern part of the country to use the Dunaföldvár bridge, they pass through the Southern Railway Bridge at Budapest instead. However, when line 150 becomes faster in scenario \#3, these paths reroute again: between stations in the northwest and stations of lines 42 and 43 they begin to pass through both the Southern Railway Bridge at Budapest and the Dunaföldvár bridge.

A further progress in scenario \#3 compared to scenario \#2 is the appearance of paths from the north-eastern regions passing through the bridge. This means that in this scenario the Dunaföldvár bridge becomes an alternative for the Southern bridge. Paths in the 
Debrecen/Nyíregyháza direction do not pass through the now slower line 155 but continue to the capital on line 100 and from there they use line 150, which, due to its higher line speed is now a better route.

\subsection{Change in the traffic due to the Dunaföldvár bridge}

The numerical values of measures describing each scenario are presented in Table 1.

Table 1.

The numerical values of the measures used to describe the effects of the Dunaföldvár bridge on the railway network of Hungary (Made by authors)

\begin{tabular}{|l|c|c|c|c|}
\hline & distance & \multicolumn{3}{|c|}{ time } \\
\hline \multicolumn{1}{|c|}{ scenario } & & $\# 1$ & $\# 2$ & $\# 3$ \\
\hline $\begin{array}{l}\text { percentile decrease in total network trip } \\
\text { length / total network travel time }\end{array}$ & 0.41 & 0.12 & 0.28 & 0.26 \\
\hline $\begin{array}{l}\text { decrease in the percentile ratio of number } \\
\text { of paths passing through the line section } \\
\text { with the heaviest traffic }\end{array}$ & 6.16 & 1.22 & 3.01 & 3.16 \\
\hline $\begin{array}{l}\text { percentile ratio of all shortest paths using } \\
\text { the Dunaföldvár bridge }\end{array}$ & 7.92 & 7.46 & 7.46 & 7.42 \\
\hline
\end{tabular}

If the $c_{\ell}$ and $c_{t}$ value is calculated for the network with and without the Dunaföldvár bridge for all three scenarios, the fact of its decrease in the presence of the bridge is obvious. What is not that evident is their relatively high values compared to a completely newly built alternative (the V0 line, see (Tóth-Horváth, 2019)). The decrease in the total network trip length is third as the value for V0 scenarios and the same hold for travel times in the cases of scenarios \#2 and \#3. Scenario $\# 1$ describes such an underdeveloped state that the value obtained here is, actually, remarkably high.

What is surprising, is that the value for scenario \#3 is lower than for scenario \#2. This effect comes from the fact that in scenario \#3 the line speed of the whole Budapest-Kelebia line is taken to be $120 \mathrm{~km} / \mathrm{h}$. This makes the paths easy to reach Budapest, namely the Southern Railway Bridge, while there is no similar development in the western (the so-called Transdanubia) region of the country. Thus, the development of line 150 increases the importance of the Southern bridge even in the presence of a bridge with high connecting line speeds at Dunaföldvár.

This also results in the low traffic decrease on the Southern bridge, the network element with the heaviest traffic. Compared to V0 scenarios, ${ }^{17}$ the values obtained here are only as much as about one-fifth which means an ineffective redistribution of the traffic in the presence of both bridges compared to a network where the bridge at Dunaföldvár is not present.

\footnotetext{
17 Tóth and Horváth 2019.
} 
In the network without the Dunaföldvár bridge, more than half of the paths passes through the Southern Railway Bridge. ${ }^{18}$ If the Dunaföldvár bridge were built, regardless of the scenario, only about $7.5 \%$ of the paths would pass through it which means that it is a highly ineffective network element in the undisrupted network. This can also be observed in Fig. 4, where the percentile change in the number of paths is presented for the scenarios.
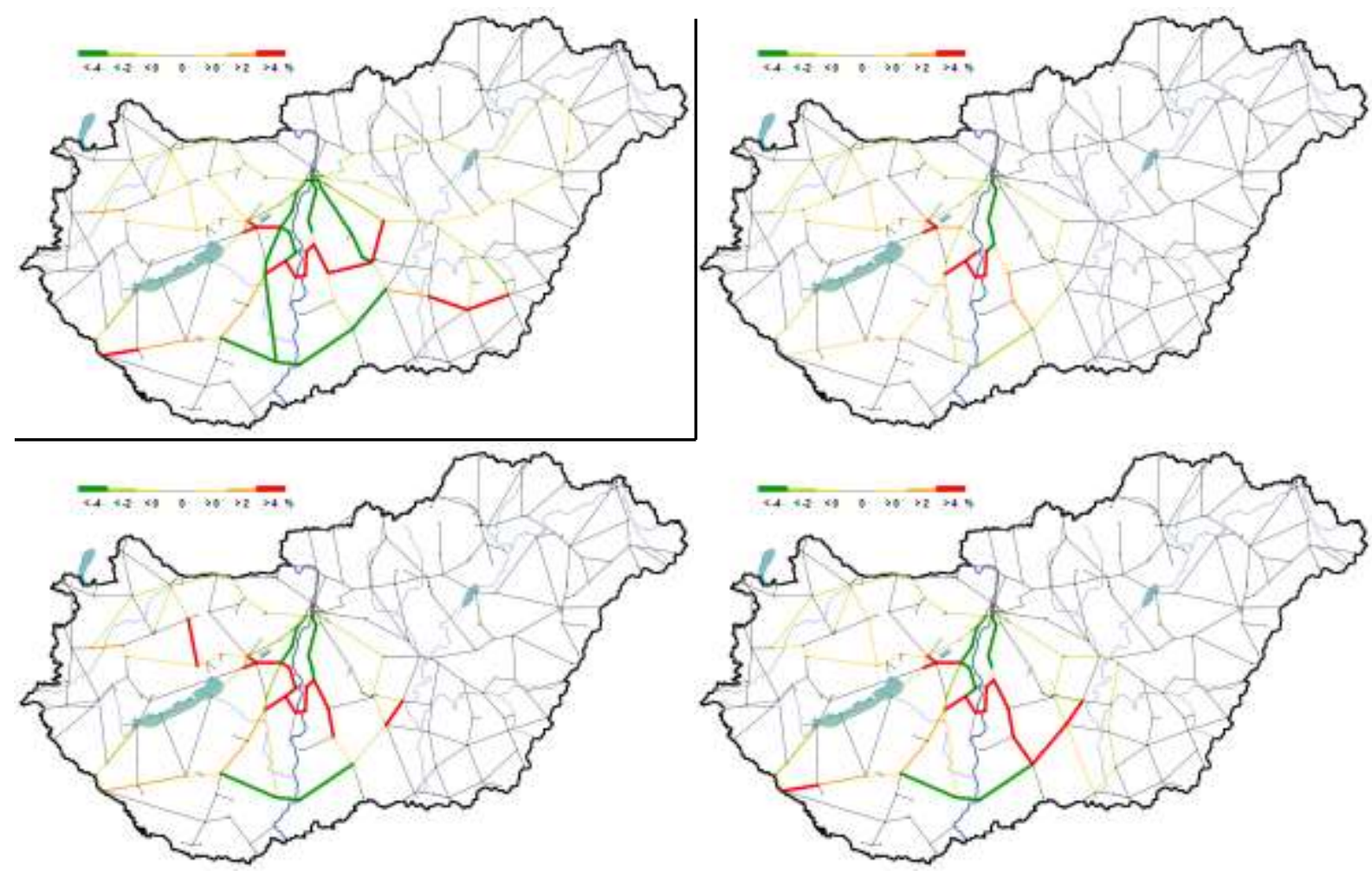

Figure 4.

The change in the percentile ratio of paths between all pairs of stations passing through each line section by introducing the three alternatives of the Dunaföldvár bridge. minimal trip lengths: top left; minimal travel times scenario \#1 top right, scenario \#2 bottom left, scenario \#3 bottom right

(Made by authors)

In every case, the regions of the country far from the bridge are not affected, the paths take their original route even when the Dunaföldvár bridge operates as an element of the network.

For the paths with minimal length, only the main lines near the Dunaföldvár bridge and the Baja bridge are disencumbered. Here, only paths connecting the central regions of the Transdanubia and Cisdanubia regions use this bridge instead of taking a long detour via Baja or Budapest. The same holds for scenario \#3 for paths with minimal travel times. For scenario \#2, the extension of the positively affected regions is much smaller while for scenario \#1 it almost disappears.

This leads to the conclusion that by having a bridge at Dunaföldvár and also increasing the line speed of most connecting lines, the bridge plays a quite small role in the handling of the traffic crossing the Danube in Hungary, due to its distant location from main lines 40 and 150 and also being accessible only on a relatively long route via lines 42,43 and 151 .

\footnotetext{
${ }^{18}$ Tóth 2020.
} 


\subsection{Redundancy provided by the Dunaföldvár bridge}

Though the Dunaföldvár bridge plays an insignificant role in an undisrupted network, it can be an important network element in the case of disruptions. In the following, we will analyse what happens to the distribution of the traffic when the Southern Railway Bridge in Budapest is disrupted (see Fig. 5).

If the paths with minimal length are considered, the Dunaföldvár bridge has approximately the same importance as the Újpest Railway bridge. In a network without the Dunaföldvár bridge, practically all of the traffic is rerouted through the Ujpest bridge, ${ }^{19}$ but when present only half of the rerouted traffic crosses the Danube at Újpest even though that route is only $8 \mathrm{~km}$ longer on average than the route through the Southern bridge. ${ }^{20}$ The lines from which most traffic disappears are line 100 (Szolnok-Cegléd-Budapest), from which the traffic crossing the Danube at Újpest takes the direction through line 120 through Újszász and line 10 through Pápa and Celldömölk. The Dunaföldvár bridge is reached through the previously mentioned line 155 (Fülöpszállás-Kecskemét) and also line 150 (Budapest-Kelebia) and continues westwards on lines 42, 43 and 44 through Székesfehérvár and Rétszilas.
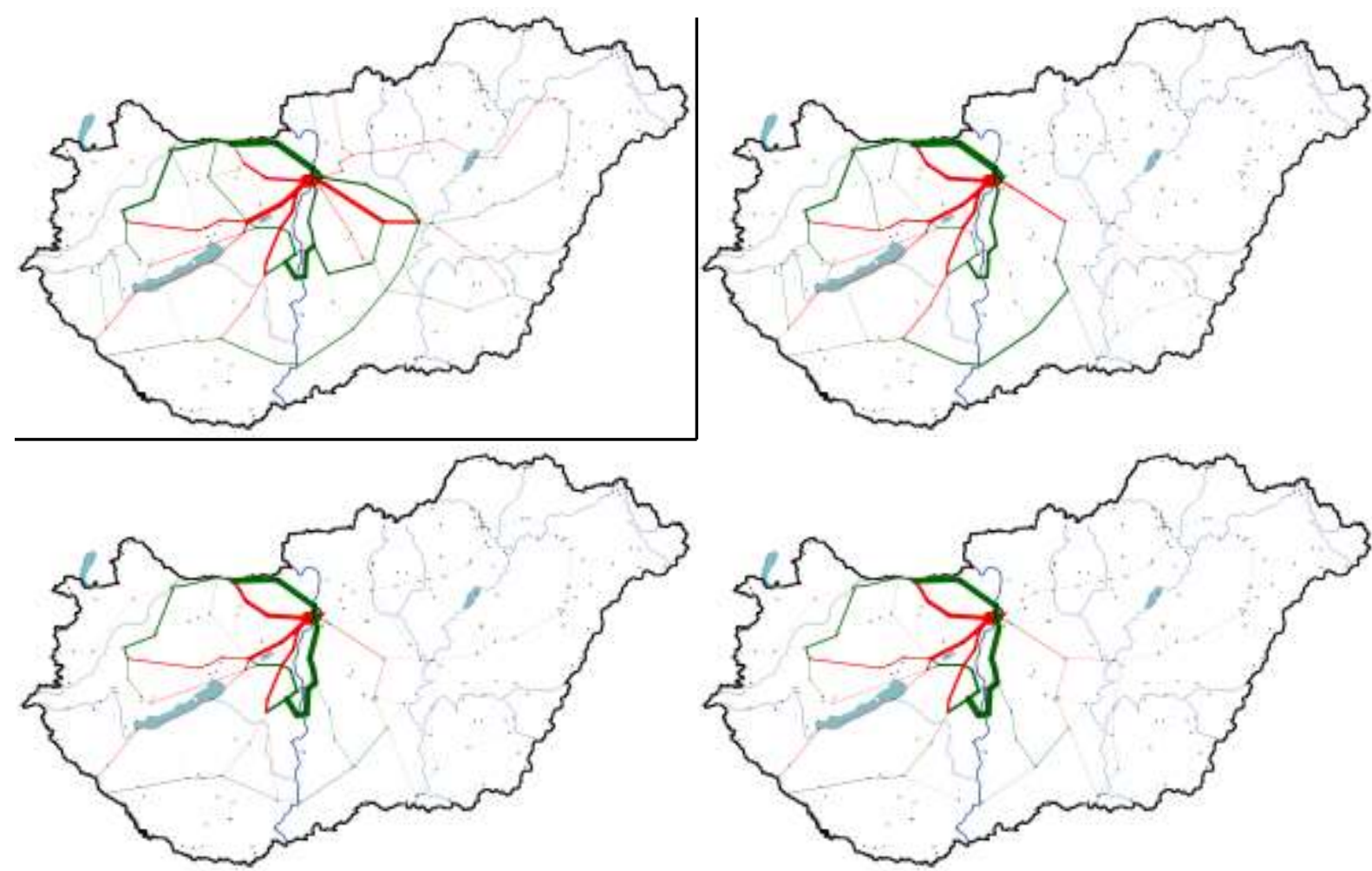

Figure 5.

The redistribution of paths with shortest trip length on the disruption of the Southern Railway Bridge (top left) and with shortest travel time according to scenarios \#1 (top right), \#2 (bottom left) and \#3 (bottom right). The thickness of the lines is proportional to the change in number of paths passing through each line section red indicating decrease and green indicating increase

(Made by authors)

\footnotetext{
19 Tóth and Horváth 2019.

20 Tóth 2019.
} 
The situation is mainly the same in the case of scenario \#3, except for the omission of line 155 by the traffic due to its low line speed. Therefore, the paths eastwards of Budapest approach the capital on their original route and then take the now fast line 150 to Kunszentmiklós-Tass.

As the line speed of line 150 and then lines 151, 42, 43 and 44 are taken to be lower in scenarios \#2 and \#1, one sees the increasing loss of traffic through the Dunaföldvár bridge and its redistribution to the Újpest and Baja bridges making it more and more like the network without the Dunaföldvár bridge. ${ }^{21}$ In the case of scenario \#1, only paths originally passing the Southern Railway Bridge cross the Danube at Dunaföldvár, which connects regions in the vicinity of the Dunaföldvár bridge on both sides of the Danube. Paths that connect more distant regions cross the Danube through the other two remaining bridges as the lines that connect them to the network have higher line speeds, moreover, lack the need for reversing(s) which is often needed when using the bridge at Dunaföldvár. To quantify the statements above, the redundancy of the Dunaföldvár bridge was calculated for all three scenarios. The results can be seen in Fig. 6 along with results of previous analyses.

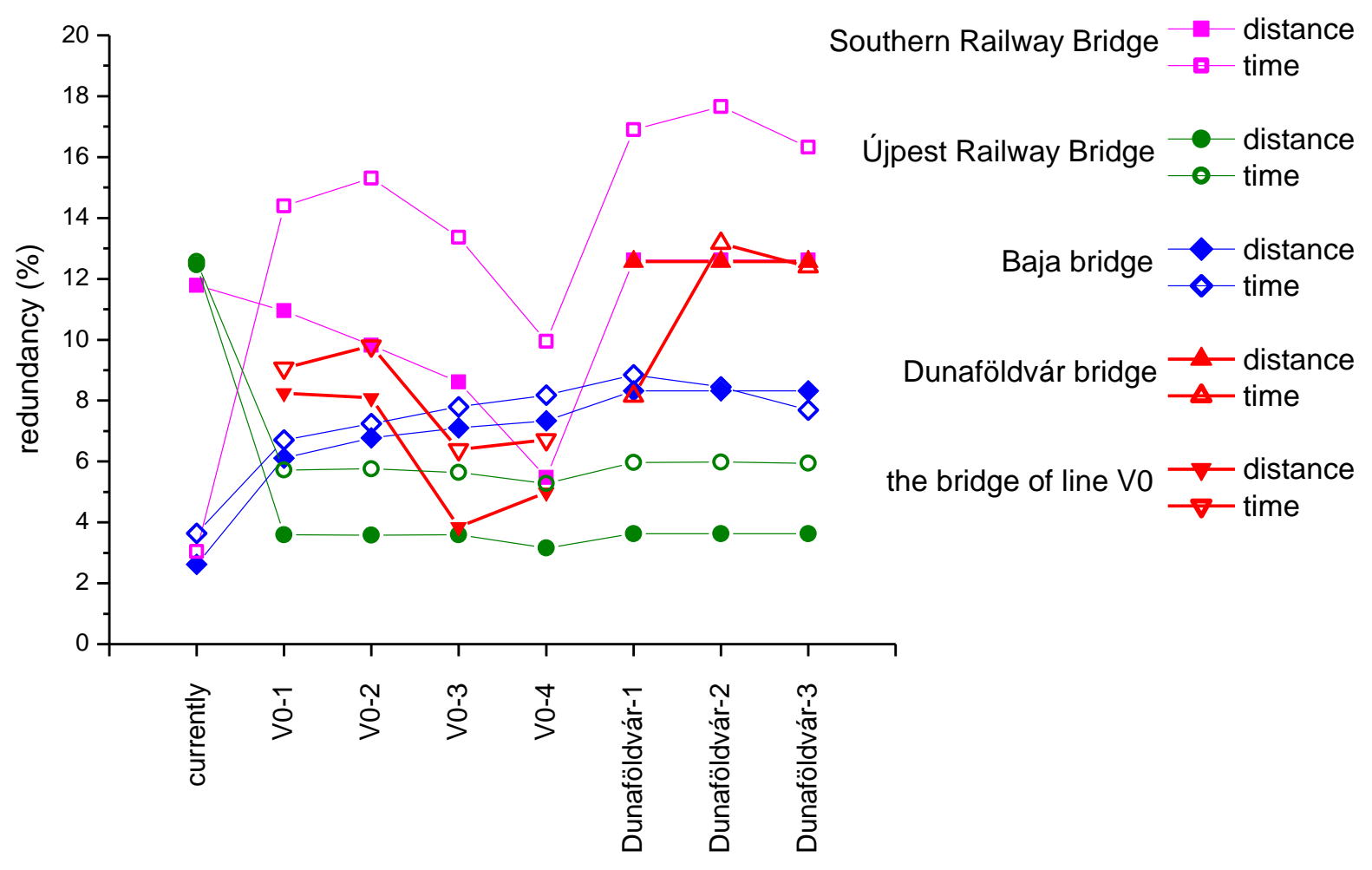

Figure 6.

The $r^{u}$ ' percentile redundancy values calculated using Eqs. (9) and (10), u being the line sections containing the Southern Railway Bridge (square), the Újpest Railway Bridge (circle), the Danube Bridge at Baja (upward triangle) and the Dunaföldvár bridge (upward triangle) or the Danube bridge of the VO line (downward triangle). Each value is calculated for the network without the fourth bridge (i.e. the Dunaföldvár bridge or the one of the VO line) (w/o a $4^{\text {th }}$ bridge), the three

\footnotetext{
${ }^{21}$ Tóth and Horváth 2019.
} 


\section{Dunaföldvár scenarios and the four V0 alternatives presented (Tóth-Horváth, 2019) for paths with the shortest trip length (closed symbol) and the shortest travel time (open symbol)}

(Made by authors)

The results show that (while the redundancy of scenario \#1 is of minor importance in the case of minimal travel times) the Dunaföldvár bridge in its \#2 and \#3 scenarios is an efficient bridge in providing redundancy to the network. It even has about 1.5 times higher $r$ ' value than the bridge of any V0 alternative. This high value originates in the circumstance that if it is also disrupted, the traffic has to be rerouted either via the Újpest or the Baja bridge, both of which are connected into the network with lines with low speed.

We also have to mention that, from a railway operation aspect, the detours through the Újpest and Baja bridges lead to huge problems because of the low capacity of the connecting lines. That would result in cutting or cancelling many of the paths. ${ }^{22}$

\section{Conclusion}

As it has been shown by calculations on a graph model of the railway network of Hungary using different measures to quantify its properties, a railway bridge at Dunaföldvár could not have been an important element of the network even if several connecting lines were developed. On the other hand, it would have been a vital element in the network in the case of the disruption of Southern Railway Bridge at Budapest, the heaviest loaded crossing, which is also the only double tracked and electrified bridge on the Danube in Hungary.

As the tracks are currently no longer present between Solt and Dunaföldvár, only a brownfield redevelopment could be carried out. However, the old path of the tracks makes it impossible to increase the line speed to $120 \mathrm{~km} / \mathrm{h}$, which was used in this paper. If this line speed value is to be reached, a new path has to be decided on. In this case, one has the possibility to design the path in a way that the new bridge could be an intensively used element in the network even when the Southern Railway Bridge is fully operational. The bridge and the new line can be used as an alternative of V0 line as well.

A freight and passenger transport concept, part of the defence preparations of the country, has to include a new bridge over the Danube. For this, new possible paths have to be analysed which could be the topic of another paper.

\footnotetext{
${ }^{22}$ Horváth 2006.
} 


\section{REFERENCES}

Crucitti, P., Latora, V., Marchiori, M. and Rapisarda, A. 2003. "Efficiency of scale-free networks: error and attack tolerance." Physica A 320: 622-642.

https://doi.org/10.1016/S0378-4371(02)01545-5

Crucitti, P., Latora, V., Marchiori, M. and Rapisarda, A. 2004. "Error and attack tolerance of complex networks." Physica A 340 (1-3): 388-394.

https://doi.org/10.1016/j.physa.2004.04.031

Csardi, G. and Nepusz, T. 2006. "The igraph software package for complex network research.” InterJournal, Complex Systems 1695. http://igraph.org

Derrible, S. and Kennedy, C. 2011. "Applications of Graph Theory and Network Science to Transit Network Design.” Transport Reviews 31(4): 495-519.

https://doi.org/10.1080/01441647.2010.543709

Dijkstra, E. W. 1959. "A note on two problems in connexion with graphs." Numerische Mathematik 1(1): 269-271.

https://doi.org/10.1007/BF01386390,

URL:

WWWm3.ma.tum.de/foswiki/pub/MN0506/WebHome/dijkstra.pdf

Homolya, R. (s. a.): Magyarország folyamatban lévő és tervezett közlekedési beruházásai. www.ktenet.hu/download.php?edid=1483\&usg=AOvVaw275bTK3zb5fU44k_Yakc0N

Horváth, A. 2005. A közlekedési hálózat és a védelmi érdek kapcsolata. Budapest: Zrínyi Miklós Nemzetvédelmi Egyetem.

Horváth, A. 2006. A közúti, vasúti és vízi közlekedés terrorfenyegetettségének jellemzői. In Válaszok a terrorizmusra, szerk. Tálas, P., II. 321-336. Budapest: Mágustúdió.

Horváth, A. 2009. Közlekedési hálózat és az ország védelmi képesség kapcsolata. Biztonságpolitika: Biztonságpolitikai szakportál URL: http://old.biztonsagpolitika.hu/documents/1277414270_horvath_attila_kozlekedesi_haloz at_es_az_orszag_vedelem_kepesseg_kapcsolata___biztonsagpolitika.hu.pdf

Jenelius, E., Petersen, T. and Mattson, L-G. 2006. "Importance and exposure in road network vulnerability analysis." Transp. Res. A Vol. 40: 537-560.

https://doi.org/10.1016/j.tra.2005.11.003

Jenelius, E. 2010. "Redundancy importance: Links as rerouting alternatives during road network disruptions." Procedia Engineering Vol. 3: 129-137.

https://doi.org/10.1016/j.proeng.2010.07.013,

URL: https://www.sciencedirect.com/science/article/pii/S1877705810004820/pdf?md5=6fef01 29a7646468761bad5506b12aab\&pid=1-s2.0-S1877705810004820-main.pdf

Lakatos, P., Szászi, G., Taksás, B. 2016. A logisztikai infrastruktúra szerepe a regionális versenyképesség alakításában In Regionális versenyképességi tanulmányok, szerk. Csath, M., 181-228. Budapest: NKE Szolgáltató Nonprofit Kft.

Lévai, Zs. 2020. A vasúti alágazat jelenkori kapcsolódása a közlekedési támogatás rendszeréhez. Katonai Logisztika Vol. 28, no. 1-2: 198-223.

https://doi.org/10.30583/2020/1-2/198

https://drive.google.com/file/d/14cX6DMOs_ZVf2U5YhnMyKsaxU-vtGqM-/view 
Mattsson, L. G. and Jenelius, E. 2015. "Vulnerability and resilience of transport systems - A discussion of recent research." Transportation Research Part A Vol. 81: 16-34. https://doi.org/10.1016/j.tra.2015.06.002

Mosóczi, L. 2019. A közlekedésfejlesztés aktuális kérdései. http://www.fomterv.hu/mmk/sites/default/files/Siofok2019/01_mosoczi_laszlo_mmk_kozlfejlkonf_20190514_A.pdf

$\mathrm{R}$ Core Team 2012. R: A language and environment for statistical computing. Vienna, Austria: R Foundation for Statistical Computing. ISBN 3-900051-07-0 URL http://www.R-project.org/

Scott, D. M., Novak, D. C., Aultman-Hall, L. and Guo, F. 2006. ”Network Robustness Index: A new method for identifying critical links and evaluating performance for transportation networks." J. Transp. Geogr. Vol. 14, no. 3: 215-227.

https://doi.org/10.1016/j.jtrangeo.2005.10.003

Szászi, G. 2007. Magyarország közlekedési infrastruktúrájának fejlesztése napjainkban: Közút vagy vasút? Katonai Logisztika Vol. 15, no. 2: 32-59.

Szászi, G. 2009. A védelmi szempontból meghatározó repülőterek vasúti kapcsolatának helyzete Magyarországon. Repüléstudományi Kölzemények Vol. 21, Special Issue 122.

Szászi, G. 2013. Long-span railway bridges in the transport system of Hungary. Hadmérnök 8 (2): 98-107., URL: hadmernok.hu/132_09_szaszig.pdf

Szászi, G. 2014. Nagyfolyami vasúti hidak, mint közlekedési létfontosságú rendszerelemek. In Fejezetek a létfontosságú közlekedési rendszerelemek védelmének aktuális kérdéseiröl, ed. by Horváth, A., Bányász, P. and Orbók, Á., 27-46. Budapest: Nemzeti Közszolgálati Egyetem.

Tóth, B. 2017. Állomások és állomásközök zavarának gráfelméleti alapú vizsgálata a magyarországi vasúthálózaton. Hadmérnök Vol. 12, no. 4: 52-66., URL: http://hadmernok.hu/174_06_toth.pdf

Tóth, B. 2019. Redundancy Analysis of the Railway Network of Hungary. In Solutions for Sustainable Development: Proceedings of the 1 st International Conference on Engineering Solutions for Sustainable Development (ICESSD 2019), October 3-4, 2019, ed, by K. Szita Tóthné, K. Jármai and K. Voith, Miskolc, Hungary: CRC Press, 358-368. ISBN 9780367424251, eBook ISBN 9780367824037

https://doi.org/10.1201/9780367824037-42

Tóth, B. 2020. "The effect of attacks on the railway network of Hungary." Central European Journal of Operations Research,

https://doi.org/10.1007/s10100-020-00684-8

Tóth, B. G., Horváth, I. 2019. "How the Planned V0 Railway Line Would Increase the Resilience of the Railway Network of Hungary Against Attacks." Academic and Applied Research in Military and Public Management Science Vol. 18, no. 3: 109-129., URL: https://folyoiratok.uni-nke.hu/document/nkeszolgaltato-uni-nke-hu/9_Toth_Horvath.pdf

URL1: http://hirek.logportal.hu/hataridore-elkeszult-a-v0-megvalosithatosagi-tanulmanya-aszakma-javaslatott-tett-a-budapestet-elkerulo-vasutvonal-nyomvonalara 
URL2: 1372/2016. (VII. 20.) Korm. határozat egyes kulcsfontosságú budapesti közlekedési beruházások előkészítésének forrásigényéröl. www.kozlonyok.hu/nkonline/MKPDF/hiteles/MK16107.pdf

URL3: Mi épülhet vasúton 2020-ig? http://iho.hu/hir/mi-epulhet-a-vasuton-2020-ig-160630

URL4: Magyarország vasúti személyszállítási térképe. http://www.logsped.hu/vt_2013.jpg

URL5: Vasútvonalak. http://www.vpe.hu/takt/vonal_lista.php

URL6: 277/2014. (XI. 14.) Korm. rendelet a vasúti közlekedési hatóság által kiszabható bírság mértékéről és megfizetésének részletes szabályairól, 2. melléklet https://net.jogtar.hu/jogszabaly?docid=a1400277.kor 